\title{
DAMPAK OBJEK WISATA BUKIT KASIH TERHADAP PENDAPATAN MASYARAKAT DI DESA KANONANG DUA KECAMATAN KAWANGKOAN BARAT
}

\author{
Meilan Hardina Wowor \\ Gene H. M. Kapantow \\ Eyverson Ruauw
}

\begin{abstract}
This study aims to look at the impact of Bukit Kasih tourism objects on the income of the people of Kanonang Dua Village who did business on the tourist attraction area. This research was carried out for 3 months from namely May to July 2018. The data used was primary data, through direct interviews with 30 respondents, namely those who run businesses in the Bukit Kasih Tourism Area. Secondary data obtained through the internet by using google searching to access scientific journal articles and thesis from other universities that relevant with the research. The sampling technique used was purposive sampling. This study used an analysis of the average difference through the t-test, the impact was measured by comparing income before and after doing business in the tourism area. The results showed that there was a significant increase in income for the people who doing business at the Bukit Kasih Tourism Area. The average income of the community before doing business in the tourist area was Rp. 883,333 per month and increased to Rp. 2,390,000 per month after doing business in the Bukit Kasih Tourism Area. This means that the average income increases by 1.506.667,00,- "
\end{abstract}

Keywords: the impact of tourism objects, income, t-test, Kanonang Village, Minahasa Regency

\begin{abstract}
ABSTRAK
Penelitian ini bertujuan untuk melihat dampak objek wisata Bukit Kasih terhadap pendapatan masyarakat Desa Kanonang Dua yang berusaha di objek wisata tersebut. Penelitian ini di laksanakan selama 3 bulan yaitu bulan Mei sampai Juli 2018. Data yang digunakan yaitu data primer yaitu melalui wawancara langsung pada 30 responden yaitu yang menjalankan usaha di Kawasan Objek Wisata Bukit Kasih. Data sekunder diperoleh melalui internet dengan menggunakan google searching untuk mengakses artikel jurnal ilmiah dan skripsi dari perguruan tinggi lainnya ada kaitannya dengan topik penelitian ini yaitu tentang dampak objek wisata. Teknik pengambilan sampel yang digunakan adalah secara sengaja (purposive sampling). Penelitian ini menggunakan analisis uji beda rata-rata melalui uji-t, Dampak tersebut di ukur dengan membandingkan pendapatan sebelum dan sesudah berusaha di Kawasan Objek Wisata Bukit Kasih. Hasil penelitian menunjukkan bahwa terjadi peningkatan pendapatan yang signifikan bagi masyarakat yang berusaha di Kawasan Objek Wisata Bukit Kasih. Pendapatan rata-rata Masyarakat sebelum berusaha di kawasan objek wisata adalah Rp.883.333,-- per bulan dan meningkat menjadi sebesar Rp. 2.390.000,- per bulan sesudah berusaha di Kawasan Objek Wisata Bukit Kasih. 1.506.667,00,- " ${ }^{\text {ghmk+eprm* }}$
\end{abstract}

Kata kunci : dampak objek wisata, pendapatan, uji-t, Desa Kanonang, Kabupaten Minahasa

\section{PENDAHULUAN}

\section{Latar Belakang}

Pariwisata merupakan industri yang banyak menghasilkan devisa bagi negara sehingga pemerintah berusaha untuk meningkatkan sektor tersebut dengan mengambil langkah-langkah kebijakan pembangunan pariwisata (Fandeli, 2000). Sektor pariwisata semakin diperhitungkan karena permintaannya semakin melonjak, terutama pada era globalisasi seperti sekarang. Pariwisata mampu mendorong pertumbuhan ekonomi terutama dalam penyediaan lapangan kerja, peningkatan penghasilan, standar hidup serta stimulus bagi perkembangan sektor-sektor lainnya (Yoeti, 2008). Upaya yang telah dilakukan pemerintah untuk mengembangkan industri pariwisata di Indonesia diantaranya mendorong tersedianya sarana akomodasi yang memadai, promosi, kemudahan perjalanan, penambahan dan pengembangan kawasan pariwisata dan terus mengupayakan produk wisata baru. Keberhasilan pembangunan sektor pariwisata nasional sangat didukung oleh peran program peningkatan serta pengembangan potensi pariwisata diseluruh wilayah Indonesia. 
Usaha pariwisata adalah kegiatan yang bertujuan menyelenggarakan jasa pariwisata atau menyediakan atau mengusahakan objek dan daya tarik wisata, usaha barang pariwisata dan usaha lain yang terkait dengan bidang tersebut. Pariwisata adalah suatu susunan organisasi, baik pemerintah maupun swasta, yang terkait dalam pengembangan, produksi dan pemasaran produk suatu layanan untuk memenuhi kebutuhan dari orang yang sedang berpergian.

Potensi peluang parawisata adalah bagaimana sektor ini menjadi bagian dari pembangunan yang memiliki nilai dan posisi strategis yang memberi multi pengaruh baik secara langsung maupun tidak kepada suatu daerah. Selain mampu memberi nilai ekonomi dan nilai komersial yang besar, pada dasarnya sektor pariwisata juga mempunyai potensi lain bersifat sosial seperti peningkatan pendapatan, peningkatan kualitas nilai sosial budaya, integritas dan jatidiri, perluasan wawasan, konservasi alam dan peningkatan mutu lingkungan (Suhandi, 2003).

Industri masyarakat suatu daerah merupakan unsur penunjang bagi wisatawan sebagai konsumsi dari dampak kunjungan mereka ke destinasi pariwisata. Usaha dari industri jasa tersebut terdiri dari berbagai item yang bersifat habis seperti makanan, cenderamata (kerajinan tangan, tenun, dan sebagainya) Barang-barang souvenir yang dominan dihasilkan dari kreativitas ini, berdampak ganda bagi kedua belah pihak yakni masyarakat dan wisatawan. Disinilah arti pentingnya kemampuan menangkap peluang dari kemajuan pariwisata untuk meningkatkan pendapatan suatu daerah.

Sebagai salah satu daerah tujuan wisata, Provinsi Sulawesi Utara yang memiliki kekayaan budaya yang unik, keindahan alam dan keramahan penduduk yang merupakan aset negara yang sangat potensial untuk terus dikembangkan dan dikelola oleh Pemerintah Daerah, dalam hal ini Dinas Kebudayaan dan Pariwisata Provinsi Sulawesi Utara bersama dengan masyarakat berupaya mengembangkan objek pariwisata yang ada di Sulawesi Utara khususnya pariwisata yang ada di desa Kanonang kecamatan Kawangkoan Barat.
Keberadaan objek wisata Bukit Kasih yang ada di Desa Kanonang Kecamatan Kawangkoan Barat tidak hanya menguntungkan pemerintah daerah tetapi juga bagi masyarakat di sekitar kawasan objek wisata tersebut. Bukit Kasih merupakan salah satu objek wista yang ada di Provinsi Sulawesi Utara yang memiliki potensi wisata yang unggul dan strategis. Sebagian penduduk Desa Kanonang membuka usaha di Kawasan objek wisata Bukit Kasih.

Tabel 1. Jumlah dan Jenis Usaha Yang Ada di Kawasan Wisata Bukit Kasih

\begin{tabular}{clc}
\hline No & Jenis Usaha & Jumlah \\
\hline 1 & Rumah Makan & 22 \\
2 & Tukang Foto & 20 \\
3 & Tukang Pijat & 15 \\
4 & Penjual Aksesoris & 20 \\
\hline & Total & 77 \\
\hline
\end{tabular}

Sumber : Badan Pusat Statistik Minahasa, 2018

Keberadaan Objek Wisata Bukit Kasih yang telah memberikan lapangan kerja bagi masyarakat sekitarnya sangat berpotensi untuk meningkatkan pendapatan masyarakat. Oleh karena itu, perlu diadakan penelitian mengenai dampak Objek Wisata Bukit Kasih di Desa Kanonang Dua Kecamatan Kawangkoan Barat.

\section{Pariwisata}

Kata pariwisata baru popular di Indonesia setelah diselenggarakannya Musyawarah Nasional Tourisme ke II di Tretes, Jawa Timur pada tanggal 12 sampai dengan 14 Juni 1958. Sebelumnya sebagai ganti kata "pariwisata" digunakan kata "tourisme" yang berasal dari bahasa Belanda. Adapun orang yang berjasa mempopulerkan kata pariwisata atau adalah Jendral G.P.H Djatikusumo yang pada saat itu menjabat Menteri Perhubungan Darat, Pos, Telekomunikasi dan Pariwisata.

Menurut Yoeti dalam Biantoro (2014), pengertian pariwisata sebagai suatu perjalanan yang dilakukan untuk sementara waktu, diselenggarakan dari suatu tempat ke tempat lain, dengan maksud bukan untuk mencari nafkah di tempat yang dikunjungi, melainkan untuk menikmati perjalanan tersebut guna memenuhi keinginan yang beranekaragam. Kegiatan pariwisata yang dikelola dengan baik dapat menghasilkan manfaat ekonomi yang berarti dengan pemanfaatan yang berdampak kecil terhadap kawasan lindung. Kegiatan pariwisata 
pada daerah yang dilindungi, bila diatur dan dikendalikan secara baik akan mengarah pada pemanfaatan ekonomi dengan dampak kerusakan yang minimum. Peningkatan kepedulian terhadap sumberdaya alam secara universal menyebabkan timbulnya bentuk kegiatan wisata yang berbasis kepada alam. Salah satu bentuk kegiatan wisata alam tersebut adalah ekowisata yang dapat didefinisikan sebagai penggunaan daerah yang alami oleh pengunjung berjumlah kecil yang memiliki kemampuan dan pengetahuan dengan tujuan untuk mempelajari suatu pengalamam baru.

Menurut Munasef dalam Lutfi (2013), kegiatan pariwisata terdiri dari tiga unsur, diantaranya :

a) Manusia (human) yang merupakan orang yang melakukan perjalanan dengan maksud menikmati keindahan suatu tempat (alam).

b) Ruang (space) yang merupakan daerah atau ruang lingkup tempat melakukan perjalanan.

c) Waktu (time) yang merupakan waktu yang digunakan selama dalam perjalanan dan tinggal di daerah tujuan wisata.

Kelly (1998) dalam Sulaksmi (2007) mengutarakan klasifikasi bentuk wisata yang dikembangkan berdasarkan pada bentuk utama atraksi (attractions) atau daya tariknya yang kemudian ditekankan pada pemasarannya. Bentuk wisata tersebut antara lain berupa: ekowisata (ecotourism), wisata alam (nature tourism), wisata pertualangan (adventure tourism), wisata berdasarkan waktu (getaway and stay) dan wisata budaya (cultural tourism).

Menurut Gunn (1994) dalam Navila (2013), bentuk-bentuk wisata dikembangkan dan direncanakan berdasarkan hal berikut ini :

1) Kepemilikan (ownership) atau pengelolaan areal wisata tersebut yang dapat dikelompokkan ke dalam tiga sektor, yaitu sektor bidang pemerintahan, sektor organisasi nirlaba, dan perusahaan konvensional

2) Sumberdaya (resource), yaitu alam (natural) atau budaya (cultural)

3) Perjalanan wisata/lama tinggal (touring/ longstay)

4) Tempat kegiatan yaitu di dalam ruangan (indoor) atau di luar ruangan (outdoor);

5) Wisatawan utama/wisatawan penunjang (primary/secondary)

6) Daya dukung (carrying capacity) tapak dengan tingkat penggunaan pengunjung yaitu intensif, semi intensif dan ekstensif.
Selanjutnya Gunn (1994) mengutarakan bahwa wisata alam merupakan kegiatan wisata dengan atraksi utamanya adalah sumberdaya alam yang terdiri dari lima bentukan dasar alam, yaitu: air, perubahan topografi, flora, fauna, dan iklim. Bentuk sumber daya alam yang sangat umum untuk dikembangkan adalah air, seperti telaga warna, danau, laut, air terjun dan sebagainya. Potensi alam seperti daerah yang memiliki perbedaan ketinggian tertentu dan mengalami modifikasi landskap akan sangat menarik bagi wisatawan. Flora dan fauna endemik yang sangat bervariatif sangat menarik wisatawan, bentuk wisata mulai dari kegiatan viewing, watching, hingga berburu (hunting) satwa. Bahkan perbedaan iklim pun dapat membuka peluang industri pariwisata. Peningkatan kepedulian terhadap sumberdaya alam secara universal menyebabkan timbulnya bentuk kegiatan wisata yang berbasis kepada alam. Salah satu bentuk kegiatan wisata alam tersebut adalah ekowisata yang dapat didefinisikan sebagai penggunaan daerah yang alami oleh pengunjung berjumlah kecil yang memiliki kemampuan dan pengetahuan dengan tujuan untuk mempelajari suatu pengalamam baru.

Menurut Fandeli dan Mukhlison (2000) dalam Hasriani (2016), pada umumnya dalam pengembangan wisata terdapat dua komponen penting yang harus dikaji. Kedua komponen tersebut adalah produk dan pasar wisata. Dari sisi produk wisata alam, komponen yang sering dievaluasi adalah :

1. Produk utama obyek yang berupa atraksi, yaitu: alam, budaya, budidaya/agro, penelitian dan sebagainya.

2. Produk penunjang obyek berupa amenitas, yaitu: sarana akomodasi (pondok wisata, bumi perkemahan, karavan, dan sebagainya), sarana konsumsi (restoran, kios makanan/minuman dan sebagainya).

Selanjutnya Fandeli dan Mukhlison (2000) dalam Hasriani (2016) menyatakan bahwa terdapat beberapa usaha yang dapat meningkatkan daya tarik wisata, usaha yang demikian ini antara lain:

a) Usaha sarana wisata, penyewaan peralatan renang, dan sebagainya

b) Usaha jasa, jasa pemandu wisata dan jasa biro perjalanan

Goeldner (2003) dalam Rasak (2017) melihat pariwisata dari empat perspektif yang berbeda yaitu dari wisatawan, pebisnis yang menyediakan pelayanan bagi wisatawan, pemerintah setempat dan masyarakat setempat. Dengan melihat keempat persperktif tersebut, 
Goeldner (2003) mendefinisikan pariwisata sebaga proses, kegiatan dan hasil yang didapat dari hubungan dan interaksi antara wisatawan, tourism-suppliers, pemerintah setempat, masyarakat setempat dan lingkungan sekitar yang dilibatkan ketertarikan dan tuan rumah dari pengunjung, Pariwisata merupakan serangkaian kegiatan yang dilakukan oleh wisatawan yang secara langung menyentuh dan melibatkan masyarakat sehingga membawa berbagai dampak terhadap masyarakat setempat. Kegiatan kepariwisataan dilakukan mulai dari keberangkatan hingga di daerah tujuan di seluruh penjuru dunia. Bahkan Dinamika dalam pariwisata ditimbulkan oleh beberapa factor sebagai berikut.

1. Pengembangan dan peningkatan penggunaan perantara perjalanan seperti biro perjalanan wisata sehingga memudahkan wisatawan untuk melakukan perencanaan perjalanan.

2. Pertumbuhan bauran pemasaran dalam menawarkan produk wisata sehingga peluang penjualan dan trasaksi wisata semakin besar.

3. Jumlah pemain di industri yang menjanjikan semakin banyak sehingga persaingan semaikin besar. Beberapa di antaranya menjalankan persaingan tidak sehat sehingga perlu ditegakkan kode etik pariwisata.

\section{Dampak Pariwisata}

Dampak Pariwisata terbagi dua yaitu yang pertama dampak positif dan yang kedua adalah dampak negatif.

\section{Dampak Positif Pariwisata}

Dampak pariwisata diukur dalam dua tahap, yaitu dampak langsung dan tidak langsung terhadap perekonomian. Dampak langsung antara lain diukur melalui tingkat belanja devisa pariwisata dan dampaknya terhadap lapangan kerja. Sementara dampak tidak langsung meliputi pengukuran efek yang ditimbulkan terhadap pendapatan nasional (pertumbuhan ekonomi). Dalam jangka panjang, efek pariwisata terhadap peningkatan pertumbuhan ekonomi dapat diidentifikasi melalui beberapa saluran yang berbeda, yaitu sebagai berikut :

a. Pariwisata adalah penghasil devisa yang cukup besar, yang tersedia untuk pembayaran barangbarang atau bahan baku dasar yang diimpor yang digunakan dalam proses produksi.

b. Pariwisata memainkan peranan penting dalam mendorong investasi pada infrastruktur baru dan persaingan antar perusahaan lokal dengan perusahaan di negara turis lainnya. c. Pariwisata menstimulasi industri-industri lainnya, baik secara langsung, tidak langsung maupun efek stimulasi.

d. Pariwisata memberikan kontribusi untuk menciptakan lapangan kerja dan meningkatkan pendapatan.

e. Pariwisata bisa menimbulkan eksploitasi yang positif dari skala ekonomis (economies of scale) perusahaan - perusahaan nasional

f. Pariwisata adalah faktor penting untuk difusi pengetahuan teknis, stimulasi riset dan pengembangan, dan akumulasi modal sumber daya manusia.

\section{Dampak Negatif}

Pariwisata Pariwisata juga membawa implikasi negatif terhadap Negara tujuan wisata (host country) dan komunitas daerahnya. Pengaruh negatif tersebut antara lain adalah :

a) Terjadinya leakages impor dan ekspor, penurunan pendapatan pekerja dan penerimaan bisnis lokal. Leakage impor meliputi pengeluaran impor untuk peralatan, makanan dan minuman, serta produk-produk lain yang tidak bisa dipenuhi oleh host country, yang sesuai dengan standar pariwisata internasional. Leakage ekspor adalah aliran keluar keuntungan yang diraih oleh investor asing yang mendanai resorts dan hotel. Para investor asing mentransfer penerimaan atau keuntungan pariwisata keluar dari host country.

b) Adanya batasan manfaat bagi masyarakat daerah yang terjadi karena pelayanan kepada turis yang serba inklusif. Keberadaan paket wisata yang "serba inklusif" dalam industry pariwisata dimana segala sesuatu tersedia, termasuk semua pengeluaran - didefinisikan menurut ukuran turis internasional dan memberikan lebih sedikit peluang bagi masyarakat daerah untuk memperoleh keuntungan dari pariwisata.

\section{Keuntungan Pariwisata}

a) Masyarakat semakin sadar akan kekayaan musik, seni, masakan, dan bahasa yang dimiliki. Selain itu, ia akan menjadikannya sebagai sebuah aset budaya yang patut dibanggakan.

b) Status sosial masyarakat meningkat karena pendapatan meningkatan, bahkan bisa memperbaiki kehidupan.

c) Kebudayaan setempat menjadi berkembang karena permintaan akan hiburan tradisional, seni, kerajinan, dan musik semakin meningkat.

d) Ketika kebudayaan disadri sebagai sebuah asset, maka upaya konservasi dan preservasi dilakukan agar kebudayaan menjadi lestari dan dapat dinikmati dlam jangka Panjang. 
e) Revitalisasi cinderamata dan kerjinan lokal yang terkadang telah lama terlupakan

f) Pariwisata dapat menghidupkan kembali pertunjukan seni dan ritual yang hamper punah.

g) Pengenalan nilai dan praktik baru serta modern yang mendorong jiwa kewirausahaan.

h) Pariwisata merupakan dorongan kuat untuk menciptakan perdamaian dan saling memahami melalui interaksi lintas budaya

i) Pemberdayaan wanita dalam berbagai posisi kerja baru di industri pariwisata, khususnya untuk industry kerajinan rumah tangga seperti kerjinan tangan dan masakan rumah tradisional.

j) Pariwisata dapat mempromosikan sebuah kebudayaan ke masyarakat luas sehingga citra masyarakat semakin terkenal. Wisatawan yang datang dapat memperkenalkan budaya masyarakat setempat kepada orang lain sehingga ia dapat mengunjungi daerah wisata tersebut.

k) Wisatawan yang berkunjung dapat memperkenalkan Bahasa dan budaya lain kepada masyarakat setempat, dan sebaliknya sehingga kemampuan berbahasa menjadi lebih baik.

Salah satu untuk meningkatkan keuntungan dan manfaat pariwisata adalah manajemen pengunjung. Managemen pengunjung di suatu obyek wisata dapat memberikan kontribusi terhadap citra suatu daerah tujuan wisata. Hal ini dapat dilakukan melalui keterlibatan seluruh elemen obyek wisata atraksi, pelayanan, penyediaan informasi yang dapat menggambarkan citra obyek wisata. Dengan melaksanakan managemen pengunjung sebaikbaiknya. Integritas obyek wisata dapat diciptakan, koordinasi dapat dijalankan dan persaingan antar obyek wisata dalam kualitas pengalaman wisata dapat berhasil.

\section{Jenis-jenis Pariwisata}

Jenis-jenis pariwisata berdasarkan motif tujuan perjalanan dapat dibedakan menjadi beberapa jenis pariwisata yaitu:

a. Pariwisata untuk menikmati perjalanan (pleasure tourism), jenis pariwisata ini dilakukan oleh orang-orang yang meninggalkan tempat tinggalnya untuk berlibur, mencari udara segar, memenuhi kehendak ingin tahunya.

b. Pariwisata untuk rekreasi (recreation ourism), pariwisata ini dilakukan untuk pemanfaatan hari libur untuk beristirahat, memulihkan kembali kesegaran jasmani dan rohaninya, dan menyegarkan diri dari keletihan dan kelelahanya dapat dilakukan pada tempat yang menjamin tujuan-tujuan rekreasi yang menawarkan kenikmatan yang diperlukan seperti tepi pantai, pegunungan, tempat-tempat peristrahatan. c. Pariwisata untuk kebudayaan (cultural tourism), jenis ini ditandai oleh adanya rangkaian motivasi, seperti keinginan untuk belajar di pusat-pusat pengajaran dan riset, mempelajari adat istiadat, kelembagaan, dan cara hidup masyarakat yang berbeda beda, mengunjungi monumen sejarah peninggalan masalalu dan keagamaan, festival, musik, teater, tarian rakyat dan lain-lain.

d. Pariwisata untuk usaha dagang (Business Tourism), menurut para ahli teori perjalanan pariwisata ini adalah bentuk profesional travel atau perjalan karena ada kaitanya dengan pekerjaan atau jabatan yang tidak memberikan seseorang untuk memilih tujuan maupun waktu perjalanan.

\section{Sarana dan Prasarana Pariwisata}

Betapa baik dan menariknya suatu atraksi yang dapat ditampilkan oleh daerah tujuan wisata, belum menarik minat wisata untuk berkunjung karena masih ada faktor lain yang menjadi pertimbangan menyangkut fasilitas-fasilitas penunjang yang memungkinkan mereka dapat menikmati kenyamanan, keamanan, dan alat-alat telekomunikasi. Terpenuhinya syarat tersebut tidak terlepas dari ketersediaan sarana dan prasarana seperti adanya jalan raya, bandar udara, pelabuhan, hotel restoran, pusat pembelanjaan, bank, kantor pos, telekomunikasi dan tempat hiburan seperti bioskop, night club dan lain-lainnya.

Walaupun keberadaan sarana dan prasarana sangat dibutuhkan, namun pengembangannya harus menghindari bahaya eksploitasi, sehingga lingkungan hidup tidak mengalami degradasi Soewantoro (2001) dalam Wolok (2016). Sarana kepariwisataan meliputi semua bentuk perusahaan yang dapat memberikan pelayanan pada wisatawan. Menurut Yoeti (1990) dalam Wolok (2016), terdapat tiga kelompok sarana kepariwisataan, meliputi:

a. Sarana pokok yang menyediakan fasilitas pokok kepariwisataan seperti hotel, travel agency, perusahaan angkutan dan lain sebagainya.

b. Sarana pelengkap yang berupa pelengkap dari sarana pokok agar wisatawan tinggal lebih lama lagi (long stay times ) seperti kolam renang, lapangan tenis, selancar angin dan sebagainya.

c. Sarana penunjang yang menunjang sarana pokok dan sarana pelengkap yang berfungsi agar wisatawan lebih banyak mengeluarkan uang di tempat yang dikunjungi seperti tempat ibadah. 
Prasarana kepariwisataan meliputi semua fasilitas yang memungkinkan proses perekonomian berjalan dengan lancar sedemikian rupa sehingga memudahkan manusia untuk memenuhi kebutuhannya. Terdapat dua prasarana kepariwisataan, yaitu :

a. Prasarana umum wisatawan, yakni: menyangkut kebutuhan umum untuk kelancaran perekonomian seperti air bersih, pelabuhan udara, terminal dan telekomunikasi.

b. Prasarana umum masyarakat keseluruhan seperti kantor pos, bank, dan sebagainya.

c. Transportasi merupakan unsur penting dalam menunjang kegiatan pariwisata baik di darat, air (laut, sungai dan danau), maupun di udara. Dalam kegiatan transportasi pariwisata, terdapat lima unsur yang satu dengan lainnya dapat dipadu menjadi satu kesatuan kerja yang mantap. Kelima unsur tersebut merupakan unsur utama yang selalu harus ada, yaitu kendaraan, awak, jaringan jalan, sasaran wisata dan wisatawannya. Kendaraan dapat berupa kendaraan darat, kendaraan air dan kendaraan udara yang betul-betul nyaman dan aman, dan merupakan salah satu unsur daya tarik wisata baik secara fisik maupun psikis Darsoprajitno (2002) dalam Mawikere (2012).

\section{Rumusan Masalah}

Bagaimana dampak Objek Wisata Bukit Kasih terhadap pendapatan masyarakat Kanonang Dua Kecamatan Kawangkoan Barat Kabupaten Minahasa?

\section{Tujuan Penelitian}

Penelitian ini bertujuan untuk mengetahui dampak objek wisata Bukit Kasih terhadap pendapatan masyarakat Desa Kanonang Dua Kecamatan Kawangkoan Barat, Kabupaten Minahasa.

\section{Manfaat Penelitian}

Penelitian ini diharapkan bisa memberikan manfaat kepada :

1. Masyarakat, yaitu memberikan informasi tentang dampak objek wisata Bukit Kasih terhadap peningkatan pendapatan masyarakat Kanonang Dua.

2. Pemerintah, yaitu memberikan informasi sebagai sumber data dalam pengembangan objek wisata Bukit Kasih di Sulawesi Utara.

\section{METODE PENELITIAN}

\section{Waktu dan Lokasi Penelitian}

Penelitian dilaksanakan selama 3 bulan yaitu bulan Mei 2018 sampai Juli 2018, mulai dari persiapan sampai penyusunan laporan. Lokasi penelitian bertempat di Objek Wisata Bukit Kasih Kecamatan Kawangkoan Barat Kabupaten Minahasa.

\section{Jenis dan Sumber Data}

Data yang digunakan dalam penelitian ini adalah data primer dan sekunder.

1. Data primer diperoleh melalui wawancara langsung yang berpedoman pada daftar pertanyaan (kuesioner),

2. Data sekunder didapat dari sumber bahan dokumentasi, hasil penelitian dan sebagainya.

\section{Metode Pengumpulan data}

Metode yang digunakan dalam penelitian di Kawasan Objek Wisata Bukit Kasih ini adalah metode survei, dengan mengumpulkan data pendapatan sebelum dan sesudah masyarakat berusaha di Kawasan Objek Wisata Bukit Kasih Kecamatan Kawangkoan Barat Kabupaten Minahasa.

\section{Teknik Pengambilan Sampel}

Teknik pengambilan sampel yang digunakan adalah purposive sampling atau secara sengaja dengan kriteria adalah masyarakat Kanonang Dua yang berusaha di Kawasan Objek Wisata Bukit Kasih Kanonang. Dari usaha yang ada di Kawasan Objek Wisata Bukit Kasih yang berjumlah 77 usaha di ambil usaha yang di kelola oleh masyarakat Desa Kanonang Dua sebanyak 30 usaha.

\section{Konsep Pengukuran Variabel}

Adapun konsep pengukuran variabel dalam penelitian ini yaitu sebagai berikut:

1. Karakteristik Responden
a. Umur Responden
b. Tingkat Pendidikan
c. Modal Usaha (Rp)

2. Pendapatan Bersih (Rp/Bulan)

a. Pendapatan sebelum berusaha di Kawasan Pariwisata Bukit Kasih

b. Pendapatan sesudah berusaha di Kawasan Pariwisata Bukit Kasih 


\section{Metode Analisis Data}

Dalam penelitian ini metode analisis data yang di gunakan adalah analisis kuantitatif yaitu analisis uji beda rata-rata melalui uji-T atau data berpasangan yaitu data pendapatan responden sebelum dan sesudah berusaha di Kawasan Objek Wisata Bukit Kasih.

\section{HASIL DAN PEMBAHASAN}

\section{Deskripsi Daerah Penelitian}

\section{Letak Geografis dan Luas Wilayah}

Desa Kanonang Dua adalah sebuah desa yang terletak di wilayah kecamatan Kawangkoan Barat, Kabupaten Minahasa, Provinsi Sulawesi Utara, mempunyai luas wilayah 125 hektar dengan batasan-batasan sekelilingnya sebagai berikut :

Sebelah utara: Kanonang Empat Kecamatan Kawangkoan Barat

Sebelah timur : Desa Pinabetengan Kecamatan Tompasa Barat

Sebelah Barat : Desa Tombasian Atas Kecamatan Kawangkoan Barat

Letak geografis Desa Kanonang Dua berada di lereng/Punggung Bukit. Letak Astronomis Desa Kanonang Dua adalah antara $01,1803^{\circ}$ LU dan $124,7799^{\circ}$ BT. Desa Kanonang Dua berada di ketinggian 804 meter di atas permukaan air laut.

Desa Kanonang Dua adalah merupakan desa pemekaran dari desa Kanonang Satu pada tahun 1977 oleh bupati Minahasa. Pelaksanaan roda pemerintahan berjalan dengan baik mengacu pada Peraturan Pemerintah Nomor 72 Tahun 2005 tentang Desa dan Struktur Organisasi Pemerintah, mengacu pada Peraturan Daerah Kabupaten Minahasa Nomor 3 Tahun 2002, sedangkan pelaksana administrasi Desa berpedoman pada Keputusan Mendagri Nomor 32 Tahun 2006 tentang Administrasi Desa.

Masyarakat Desa Kanonang Dua berjumlah 245 kepala keluarga, sedangkan jumlah penduduk 814 jiwa. Mata pencaharian Desa Kanonang Dua yaitu : tukang, PNS, buruh, jasa, pengrajin, pegawai swasta, wiraswasta, pensiunan, dan lainlain. Didukung oleh lembaga perekonomian yang ada yaitu : Koperasi, Kelompok Tani, Usaha Peternakan, Perikanan, Usaha Toko/Warung.

\section{Sejarah Kawasan Objek Wisata Bukit Kasih}

Bukit Kasih sebelumnya memiliki nama Bukit Doa lokasi ini sering digunakan masyarakat GMIM Bukit Sion untuk melakukan ibadah raya bersama-sama. Pembangunan Bukit Kasih pertama-tama diletakan batu pertama oleh beberapa pendeta sebagai keseriusan untuk mempergunakan Bukit Kasih sebagai tempat beribadah. Setelah itu tahun 2002 diresmikan menjadi Bukit Kasih oleh Gubernur A. J. Sondakh dengan harapan menjadi lokasi wisata sebagai simbol toleransi dan kerukunan umat beragama.

Bukit Kasih adalah sebuah bukit indah unik yang terletak di kaki Gunung Soputan, Desa Kanonang Kecamatan Kawangkoan Barat Kabupaten Minahasa, berjarak sekitar $55 \mathrm{~km}$ dari Kota Manado, Sulawesi Utara . Bukit Kasih yang di bangun pada tahun 2002 dengan luas $35 \mathrm{Ha}$, sesuai namanya Bukit Kasih dimaksudkan sebagai simbol bagi kerukunan dan kedamaian kehidupan umat beragama dan sebagai pusat spiritual dan setiap pengunjung yang mengunjungi Bukit Kasih bisa melaksanakan ibadah/berdoa di tempat ibadah sesuai agamanya masing-masing.

Objek Wisata Bukit Kasih Toar Lumimu'ut dikelola oleh pemerintah Provinsi Sulawesi Utara berdasarkan Peraturan Daerah Provinsi Sulawesi Utara tentang Badan Pengelola Objek Wisata Religius Bukit Kasih Kanonang Provinsi Sulawesi Utara No 5 Tahun 2005 bahwa status tanah objek wisata Bukit Kasih Kanonang kecamatan Kawangkoan Barat adalah tanah Negara dan tanah Provinsi Sulawesi Utara dengan luas $216.620 \mathrm{M}$.

Objek Wisata Bukit Kasih memberikan dampak positif bagi masyarakat Kanonang karena masyarakat mendapatkan peluang Usaha. Beragam usaha yang dimiliki oleh masyarakat yaitu membuka rumah makan, memijat dan rendam kaki dengan air belerang, menjual souvenir, banyak juga masyarakat memilih profesi menjadi tukang foto keliling.

\section{Karakteristik Responden}

\section{Tingkat Umur}

Adapun distribusi responden dalam penelitian ini dapat dijelaskan berdasarkan umur dapat dilihat pada Tabel 2. 
Tabel 2. Jumlah Umur Responden di Kawasan Obyek Wisata Bukit Kasih

\begin{tabular}{llcr}
\hline No & Umur (Tahun) & Jumlah Responden & Persentase (\%) \\
\hline 1 & $30-39$ & 9 & 30,00 \\
2 & $40-49$ & 9 & 30,00 \\
3 & $50-57$ & 7 & 23,33 \\
4 & $>58$ & 5 & 16,67 \\
\hline & Total & 30 & 100 \\
\hline
\end{tabular}

Sumber : Data diolah dari data primer, 2018

Tabel 2 menunjukkan bahwa responden berumur produktif. Hal ini dilihat dari jumlah responden dengan usia 30-39 tahun sebanyak 9 orang dengan persentase 30,00\%, 40- 49 tahun sebanyak 9 orang dengan persentase $30,00 \%, 50-57$ tahun sebanyak 7 orang dengan persentase $23,33 \%$ dan interval lebih dari 58 tahun sebanyak orang dengan persentase $16,67 \%$. Pada umumnya responden berumur 30-49 tahun atau 60 persen dari keseluruhan responden di kawasan objek wisata Bukit Kasih, kategori umur tersebut secara fisik tergolong masih kuat untuk bekerja. Umur responden sangat mempengaruhi tingkat bekerja dan tenaga sehingga mempengaruhi pendapatan.

\section{Tingkat Pendidikan}

Adapun distribusi responden dalam penelitian ini dapat dijelaskan berdasarkan tingkat pendidikan dapat dilihat pada Tabel 3.

Tabel 3. Tingkat Pendidikan Responden di Kawasan Objek Wisata Bukit Kasih

\begin{tabular}{llcr}
\hline No & Tingkat & $\begin{array}{c}\text { Jumlah } \\
\text { Pendidikan }\end{array}$ & Persentase (\%) \\
& Responden (orang) & \\
\hline 1 & SMA & 11 & 36,67 \\
2 & SMP & 13 & 43,33 \\
3 & SD & 6 & 20,00 \\
\hline & Total & 30 & 100 \\
\hline
\end{tabular}

Sumber : Data diolah dari data primer, 2018

Tabel 3 menunjukkan bahwa tingkat pendidikan responden tertinggi berada pada tingkat pendidikan SMA dengan jumlah responden 11 orang $(36,67 \%)$ sedangkan tingkat SMP dengan jumlah responden 13 orang $(43,33 \%)$, tingkat SD dengan jumlah responden 6 orang $(20,00 \%)$ dan dengan jumlah latar belakang pendidikan yang rendah yaitu sebanyak 6 orang pada tingkat SD yaitu (20,00\%). Maka dapat dikatakan bahwa tingkat pendidikan responden di kawasan objek wisata Bukit Kasih cukup relatif, karena sebagian besar responden pernah menempuh pendidikan meskipun berada pada tingkat yang berbeda. Tingkat pendidikan seseorang akan mempengaruhi kreativitas dan kemampuan seseorang dalam menerima inovasi baru, serta berpengaruh terhadap perilaku responden dalam mengelola kegiatan usahanya.

\section{Modal Usaha}

Modal merupakan faktor yang paling penting dan sangat menentukan untuk dapat memulai dan mengembangkan suatu usaha. Untuk lebih jelas mengenai jumlah modal usaha responden di kawasan objek wisata Bukit Kasih dapat di lihat pada Tabel 4.

\begin{tabular}{|c|c|c|c|c|}
\hline No & Pekerjaan & Modal (Rp) & $\begin{array}{c}\text { Jumlah } \\
\text { responden }\end{array}$ & Persentase (\%) \\
\hline 1 & Rumah Makan & $1.000 .000-2.000 .000$ & 13 & 43,33 \\
\hline 2 & Penjual Aksesoris & $500.000-1.000 .000$ & 10 & 33,34 \\
\hline 3 & Pijat refleksi & $300.000-500.000$ & 4 & 13,33 \\
\hline \multirow[t]{2}{*}{4} & Tukang Foto & $1.000 .000-1.500 .000$ & 3 & 10,00 \\
\hline & Total & & 30 & 100 \\
\hline
\end{tabular}

Tabel 4 menunjukkan bahwa distribusi responden berdasarkan modal usaha yang digunakan di kawasan objek wisata Bukit Kasih, yaitu Rumah Makan dengan modal Rp.1.000.000 - Rp.2.000.000 ada 13 responden dengan persentase 43,33\%, Penjual Aksesosris dengan modal Rp.500.000 - Rp.1.000.000 ada 10 responden dengan persentase $33,34 \%$, Pijat Refleksi dengan modal Rp.300.000 - Rp.500.000 ada 4 responden dengan persentase $13,33 \%$, dan Tukang Foto dengan modal Rp.1.000.000 Rp.1.500.000 ada 3 responden dengan persentase $10,00 \%$.

\section{Pekerjaan Responden Sebelum dan Sesudah berusaha di Kawasan Objek Wisata Bukit Kasih}

Adapun distribusi responden dalam penelitian ini dapat dijelaskan berdasarkan pekerjaan responden sebelum dan sesudah berusaha dan hasil yang diperoleh dapat dilihat sebagai berikut :

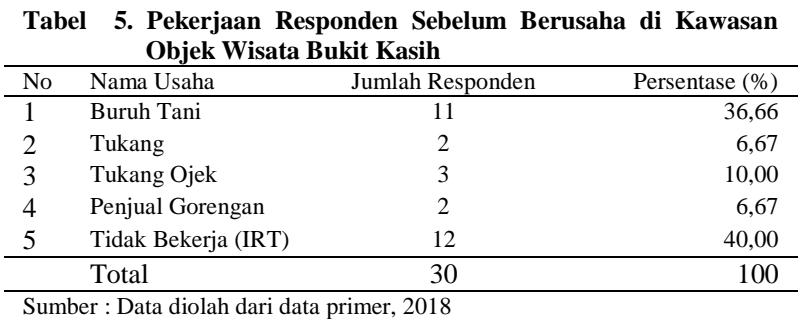

Tabel 5 menunjukkan bahwa sebelum adanya objek wisata Bukit Kasih, sebagian besar Ibu Rumah Tangga (IRT) tidak mempunyai penghasilan, dengan jumlah 12 orang dengan persentase 40,00\%, dan Buruh Tani dengan jumlah 11 orang dengan persentase 
$36,66 \%$, dan Tukang dengan jumlah 2 orang dengan persentase $6,67 \%$, dan Tukang Ojek dengan jumlah 3 orang dengan persentase $10 \%$, dan penjual gorengan sengan jumlah 2 orang dengan persentase $6,67 \%$. Hal ini menunjukkan bahwa pekerjaan responden sebelum berusaha di Kawasan Objek Wisata Bukit Kasih yang paling banyak adalah IRT, dan yang paling sedikit adalah penjual gorengan dan tukang.

Tabel 6. Pekerjaan Responden Sesudah Berusaha di Kawasan Objek Wisata Bukit Kasih

\begin{tabular}{clcr}
\hline No & Nama Usaha & Jumlah Responden & Persentase (\%) \\
\hline 1 & Rumah Makan & 13 & 43,3 \\
2 & Penjual Aksesoris & 10 & 33,4 \\
3 & Pijat Refleksi & 4 & 13,3 \\
4 & Tukang Foto & 3 & 10,00 \\
\hline & Total & 30 & 100 \\
\hline Sumber : Data diolah dari data primer, 2018
\end{tabular}

Tabel 6 menunjukkan bahwa pekerjaan responden di Kawasan Objek Wisata Bukit Kasih yang paling banyak yaitu rumah makan dengan jumlah 13 orang dengan persentase $43 \%$, dan yang paling sedikit yaitu tukang foto dengan jumlah 3 orang dengan persentase $10,00 \%$.

Pendapatan Responden Sebelum dan Sesudah Berusaha di Kawasan Objek Wisata Bukit Kasih Adapun distribusi responden dalam penelitian ini dapat dijelaskan berdasarkan pendapatan responden sebelum dan sesudah berusaha dan hasil yang diperoleh dapat dilihat pada Tabel 7.

Tabel 7. Total Pendapatan Responden Sebelum Berusaha di Kawasan \begin{tabular}{llcr}
\multicolumn{3}{c}{ Objek Wisata Bukit Kasih } & \\
\hline No & Pekerjaan & $\begin{array}{c}\text { Jumlah } \\
\text { Responden }\end{array}$ & Total Pendapatan (Rp) \\
\hline 1 Ibu Rumah Tangga & 12 & - \\
2 & Buruh tani & 11 & 17.500 .000 \\
3 & Tukang Ojek & 3 & 4.000 .000 \\
4 & Tukang & 2 & 3.500 .000 \\
5 & Penjual gorengan & 2 & 1.500 .000 \\
\hline & Jumlah & 30 & 26.500 .000 \\
\hline
\end{tabular}

Sumber : Data diolah dari data primer, 2018

Tabel 7 menunjukkan bahwa terdapat 12 responden yang sebelum berusaha di kawasan objek wisata Bukit Kasih yaitu IRT dengan total pendapatan tidak ada. Buruh tani dengan jumlah responden 11 orang dengan total pendapatan $\mathrm{Rp}$. 17. 500.000. Tukang ojek dengan jumlah responden 3 orang dengan total pendapatan $\mathrm{Rp}$. 4.000.000. Tukang dengan jumlah responden 2 orang dengan total pendapatan Rp. 3.500.000. Penjual gorengan dengan jumlah 2 responden dengan total pendapatan Rp. 1.500.000.
Tabel 8 menunjukkan bahwa pendapatan responden sesudah berusaha di kawasan objek wisata Bukit Kasih yaitu Rumah Makan dengan jumlah responden 13 orang dengan total pendapatan Rp. 36.500.000, Penjual Aksesoris dengan jumlah responden 10 orang dengan total pendapatan Rp. 22.500.000, Pijat Refleksi dengan jumlah responden 4 orang dengan total pendapatan 6.200.000, dan Tukang Foto dengan jumlah responden 3 orang dengan total pendapatan 6.500.000.

Tabel 8. Total Pendapatan Responden Sesudah Berusaha di Kawasan Objek Wisata Bukit Kasih

\begin{tabular}{clcr}
\hline No & Pekerjaan & Jumlah Responden & Pendapatan (Rp) \\
\hline 1 & Rumah Makan & 13 & 36.500 .000 \\
2 & Penjual Aksesoris & 10 & 22.500 .000 \\
3 & Pijat Refleksi & 4 & 6.200 .000 \\
4 & Tukang Foto & 3 & 6.500 .000 \\
\hline & Jumlah & 30 & 71.700 .000 \\
\hline
\end{tabular}

Sumber : Data diolah dari data primer, 2018

\section{Hasil Uji T}

Hasil analisis menunjukkan bahwa pendapatan rata-rata perbulan sesudah adanya kawasan objek wisata Bukit Kasih sebesar Rp.2.390.000 sedangkan pendapatan sebelum ratarata sebesar Rp.883.333. Ini menunjukkan terjadinya peningkatan pendapatan rata-rata yang sangat signifikan $(\alpha=5 \%)$ yaitu sebesar Rp. 1.506.667 atau meningkat sebesar $170 \%$.

Tabel 9. Hasil Uji T

\begin{tabular}{lccc}
\hline Hasil & N & Mean & StDev \\
\hline Sesudah & 30 & 2390000 & 590937 \\
Sebelum & 30 & 883333 & 806048 \\
Diferrence & 30 & 1506667 & 685783 \\
\hline Sumber
\end{tabular}

Sumber : Data yang diolah dari data primer, 2018

\section{KESIMPULAN DAN SARAN}

\section{Kesimpulan}

Objek Wisata Bukit Kasih telah memberikan dampak ekonomi berupa kenaikan pendapatan sebesar $170 \%$ bagi masyarakat yang berusaha di Kawasan Objek Wisata Bukit Kasih yang berasal dari Desa Kanonang Dua Kecamatan Kawangkoan Barat.

\section{Saran}

Objek Wisata Bukit Kasih yang berada di Kecamatan Kawangkoan Barat dapat terus di kembangkan untuk memberikan lapangan kerja yang lebih banyak bagi masyarakat sekitar kawasan objek wisata tersebut. 


\section{DAFTAR PUSTAKA}

Biantoro, R. 2014. Pengaruh Pariwisata Terhadap Karakteristik Sosial Ekonomi Masyarakat Pada Kawasan Objek Wisata Candi Borobudur Kabupaten Magelang.

Hasriani. 2016. Studi Pengembangan Objekwisata Pulau Hoga Dan Penyerapan Tenaga Kerja Di Kecamatan Kaledupa Kabupaten Wakatobi.

Lutfi. R. 2013. Peran Pariwisata Terhadap Kesejahteraan Masyarakat Di Sektor Lapangan Pekerjaan Dan Perekonomian Tahun 2009 - 2013 (Studi Kasus : Kota Batu).
Mawikere. G. 2012. Kinerja Dinas Kebudayaan Dan Pariwisata Dalam Pengembangan Pariwisata Di Provinsi Sulawesi Utara (Suatu Studi Di Dinas Kebudayaan Dan Pariwisata Provinsi Sulawesi Utara).

Navila. O. 2013. Peran Komunitas Kreatif dalam Pengembangan Pariwisata Budaya di Situs Megalitikum Gunung Padang.

Sulaksmi. R. 2007. Analisis Dampak Pariwisataterhadap Pendapatan Dan Kesejahteraan Masyarakat Sekitar Kawasan Taman Wisata Alam Laut Pulau Weh Kota Sabang.

Wolok. E. 2016. Analisis Dampak Ekonomi Wisata Hiu Paus Terhadap Pendapatan Masyarakat Batubarani Gorontalo. 